\title{
VISUALIZATION OF THE CONDUCTION SYSTEM OF HEART BY FLUORESCENCE SPECTROSCOPY*
}

\author{
E. Žurauskas ${ }^{\text {a }}$, S. Bagdonas ${ }^{\text {b }}$, L. Bandzaitytè ${ }^{\text {b }}$, G. Streckyté ${ }^{\text {b }}$, and R. Rotomskis ${ }^{b}$

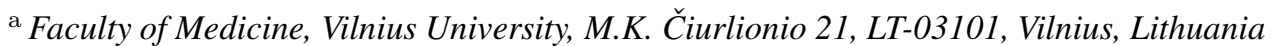 \\ ${ }^{\mathrm{b}}$ Laser Research Centre, Vilnius University, Saulètekio 9, LT-10222, Vilnius, Lithuania
}

Received 13 October 2003

\begin{abstract}
Fluorescence measurements have been employed for the spectroscopic characterization of heart tissues. Excitation at the absorption band of the aromatic amino acids allows good differentiation between tissues of the bundle of His and those of myocardium when the ratios of the fluorescence intensities measured at $340 \mathrm{~nm}$ to those at $450 \mathrm{~nm}$ are compared. Several fluorophores with overlapping fluorescence bands are responsible for autofluorescence of heart tissues in the spectral range from 350 to $550 \mathrm{~nm}$. The tissues of the bundle of His and myocardium are distinguishable by fluorescence intensity under excitation in the UVA spectral region. The best conditions are ensured by the excitation range of 360-390 nm and by recording of the fluorescence signal in the $440-480 \mathrm{~nm}$ spectral range.
\end{abstract}

Keywords: fluorescence, heart conductive system, visualization

PACS: 87.19.Hh, 87.57.Nk

\section{Introduction}

Optical diagnostic techniques based on tissue autofluorescence nowadays are widely employed in many areas of medicine due to a noninvasive, nondestructive approach and instantaneous performance. Recently fluorescence spectroscopy methods were put into practice in diagnostics of multiform heart disorders. To meet the rising requirements of the heart surgery the up-to-date visualization of the heart conduction system (HCS) is needed, which could enable one to avoid incurable accidental lesions occurring during the surgical intervention.

HCS is a complex cellular structure, which is hardly distinguishable by the naked eye from cardiac muscle, myocardium (MC). HCS has faster transmission of a bioelectrical impulse than MC and is responsible for the heartbeat (depolarization) control. Precise molecular mechanism of the combined conductive performance of the HCS cells has not been identified yet. HCS consists of the sinoatrial node (SN), the atrioventricular node (AV), the bundle of His (HB), and its right and left bundle branches.

There are only few reports concerning the studies performed on HCS by using the fluorescence spec-

\footnotetext{
* The report presented at the 35th Lithuanian National Physics Conference, 12-14 June 2003, Vilnius, Lithuania.
}

troscopy technique. The localization of the AV node was investigated in a canine heart, though no welldefined differences between the fluorescence of the AV node and that of MC tissues were observed [1]. Fluorescence intensity of auricle tissues was found being higher than that of ventricle tissues in MC samples taken from lambs [2]. The fluorescence intensity of the SN node and the AV node of the human HCS significantly differed from that of MC tissues the measured signal in both nodes was higher than in ventricle tissues and lower than in auricle tissues [3]. However, there are no reports on autofluorescence measurements of human or animal bundle of His and its branches.

During the preliminary studies performed earlier on the specimens taken from the tissues of $\mathrm{HB}$ and $\mathrm{MC}$ of human it was found that the intensity of the absorption band with a peak at about $280 \mathrm{~nm}$ in the case of the HB was significantly higher than that in the spectrum of MC [4]. The observed difference in the tissues was ascribed to the different content of the aromatic amino acids - tryptophan (Trp) and tyrosine (Tyr).

In this study the fluorescence and fluorescence excitation spectra of endogenous fluorophores of $\mathrm{HB}$ and MC were examined. 


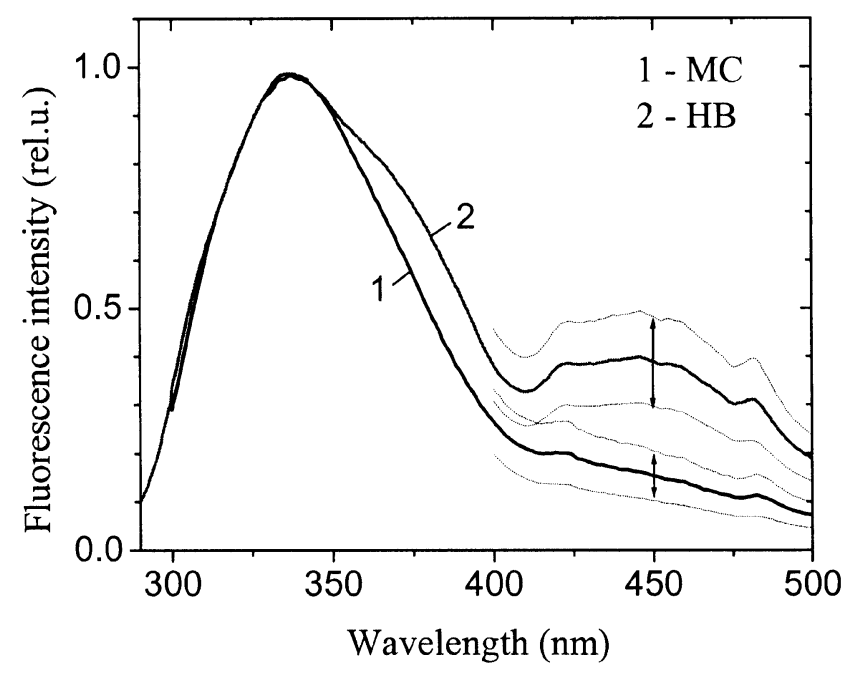

Fig. 1. Averaged fluorescence spectra of $\mathrm{HB}$ and MC tissues recorded at $255 \mathrm{~nm}$ excitation and normalized to peak intensities. Dotted curves indicate the standard deviation.

\section{Materials and methods}

The samples of the heart tissues were randomly chosen from 10 autopsy cases of different age disregarding pathology and prepared in the National Pathology Centre. The samples of HCS and MC were taken from tissues of $\mathrm{HB}$ and from tissues of ventricles, respectively. Before the measurements the specimens were kept fixed in $10 \%$ neutral solution of formaldehyde or stored at $-20^{\circ} \mathrm{C}$. Fluorescence and fluorescence excitation spectra were recorded with Perkin-Elmer spectrometer LS-50B. Images of heart tissues (Fig. 5) in daylight and fluorescent light were taken with a digital CCD camera ToUcam Pro.

\section{Results and discussion}

The fluorescence spectra of $\mathrm{HB}$ and MC were measured for 6 different heart samples and the averaged spectra are presented in Fig. 1.

Under excitation at the absorption region of the aromatic amino acids an intensive band of Trp fluorescence with a peak at $340 \mathrm{~nm}$ was observed in the fluorescence spectra of all heart tissue samples. This band seems not to be specific to a particular type of tissue and therefore it cannot be used for an unambiguous distinction between $\mathrm{HB}$ and MC tissues. However, within the spectral range of $400-500 \mathrm{~nm}$, where no Trp fluorescence is observed, the fluorescence spectra of heart tissues significantly vary in spectral shape and relative intensity (Fig. 1) and the relative fluorescence intensity of $\mathrm{HB}$ is higher than that of MC. Four bands with peaks

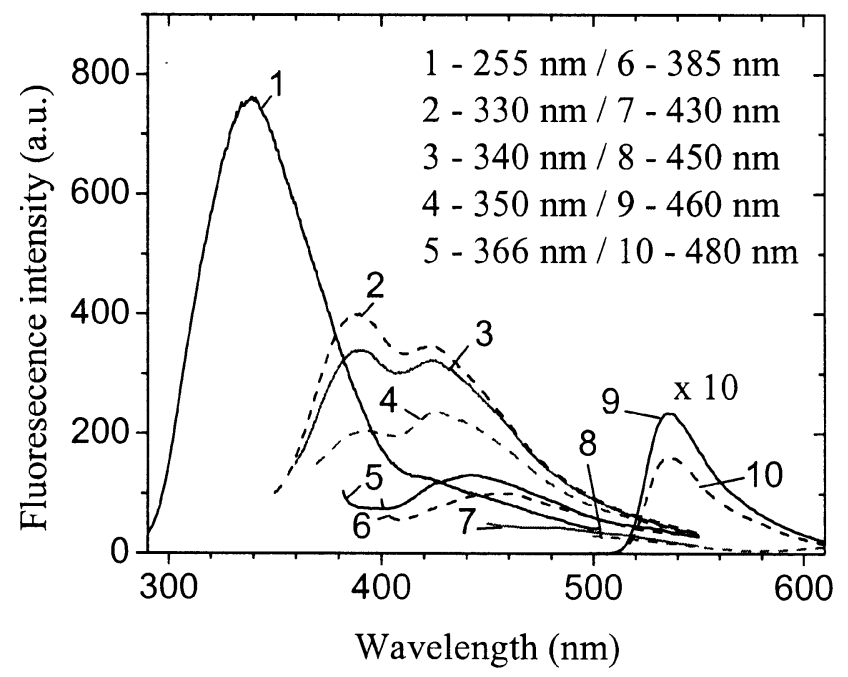

(a)

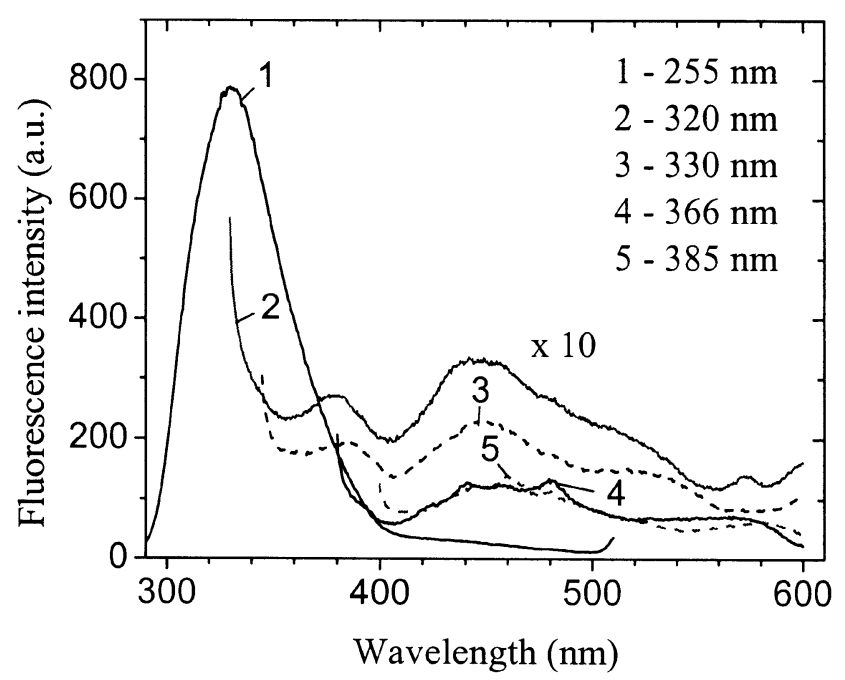

(b)

Fig. 2. Dependence of the fluorescence spectra of (a) $\mathrm{HB}$ and (b) MC on the excitation wavelength. Spectra 8-9 (a) and 2-5 (b) are scaled by a factor of 10 .

at $423,445,458$, and $482 \mathrm{~nm}$ can be distinguished in the spectrum of $\mathrm{HB}$, while two of them, at $423 \mathrm{~nm}$ and $482 \mathrm{~nm}$, are present in the spectrum of MC. The ratio of the fluorescence intensity at $340 \mathrm{~nm}$ to that at $450 \mathrm{~nm}$ was calculated for both types of tissues from the averaged fluorescence spectra: the ratios determined for $\mathrm{HB}$ and $\mathrm{MC}$ were $2.5 \pm 0.8$ and $6.4 \pm 1.8$, respectively. (A standard deviation was used for error rating, the calculated reliability of differences between tissue fluorescence intensities exceeds $91 \%$, when measured at $450 \mathrm{~nm}$.)

These results show the possibility of precise differentiation between $\mathrm{HB}$ and MC tissues based on the ratio of autofluorescence intensities in UV and blue spectral regions. Though, due to the usage of 
UV radiation for the fluorescence excitation, such method of tissue identification requires more sophisticated optical equipment and cannot be safely applied to visualize biological tissues. The spectra recorded under excitation at $255 \mathrm{~nm}$ (Fig. 1) implied that autofluorescence of the heart tissues in the blue spectral region can result from several fluorophores, which can probably be excited by light of the UVA and visible spectral regions. Therefore, the aim of the further studies was to determine the optimal wavelengths for the selective fluorescence excitation of heart tissues in the visible spectral region. For this reason, the fluorescence spectra of $\mathrm{HB}$ and $\mathrm{MC}$ were registered under various excitation conditions by changing excitation wavelength in small increments (Fig. 2).

It should be noted that under the excitation at longer wavelengths, where aromatic amino acids do not absorb, the intensity of HB fluorescence in the visible spectral region still remains significantly higher as compared with that of $\mathrm{MC}$, what can be explained by the higher concentration of some endogenous fluorophores present in HB tissues. Two new emission bands with peaks at $390 \mathrm{~nm}$ and $422 \mathrm{~nm}$ emerge in the spectra of HB under excitation at $330 \mathrm{~nm}$ (Fig.2(a)). When the excitation wavelength is increased, the relative intensities of these fluorescence bands undergo redistribution - the peak at $390 \mathrm{~nm}$ fades out, whereas the second peak broadens and shifts towards longer wavelengths. Even under excitation in the visible blue range of the spectrum $(460 \mathrm{~nm}$ and $480 \mathrm{~nm}$ ) the HB fluorescence can be detected within the wavelength region of $520-650 \mathrm{~nm}$.

The largest difference between fluorescence intensities of HB and MC tissues was detected under excitation in the spectral region of $330-385 \mathrm{~nm}$. To reveal the spectral properties of the fluorophores, which can cause the observed differences, fluorescence excitation spectra of samples were recorded (Fig. 3).

Comparison of the fluorescence excitation spectra of HB and MC tissues shows that only the bands in the UV region attributable to Trp are similar in spectra of both types of tissues. The intensity of other excitation bands in the spectra of MC is significantly lower. The longwavelength part of the HB excitation spectra consists of several overlapping bands, whose intensities and peak positions vary depending on the fluorescence emission wavelength (Fig. 3).

Analysis of fluorescence and fluorescence excitation spectra and comparison with literature data [5-8] allow one to point out potential endogenous fluorophores

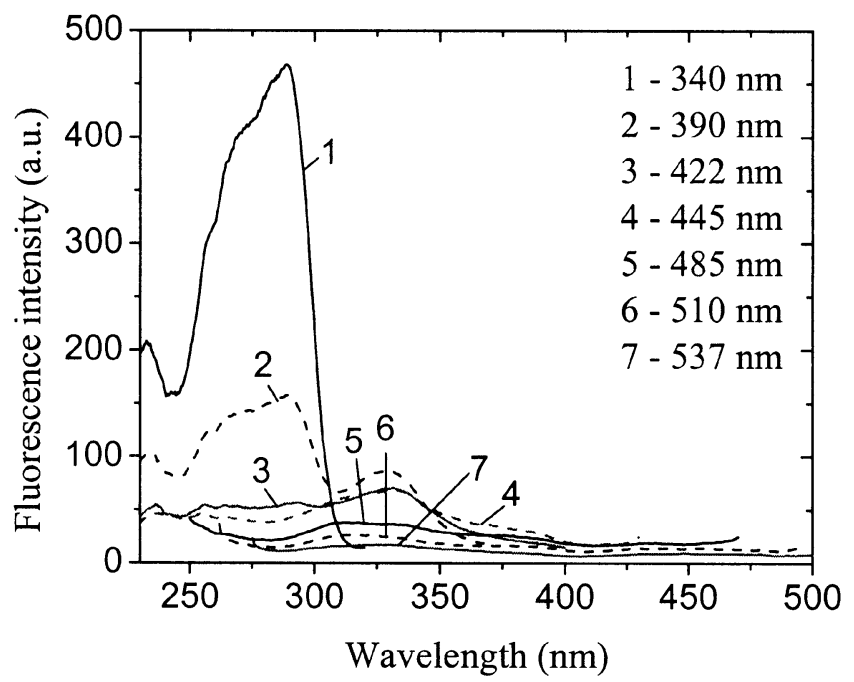

(a)

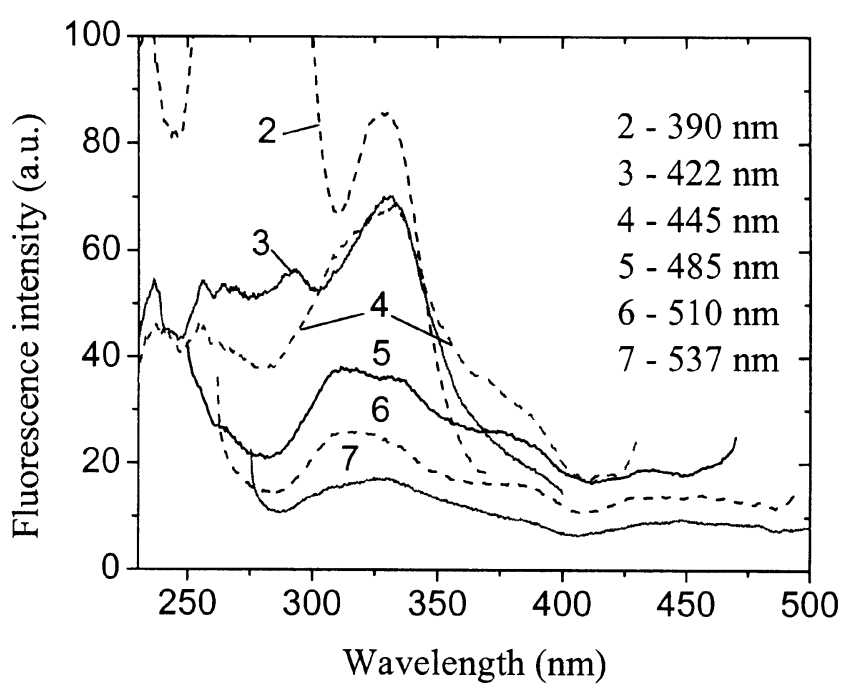

(b)

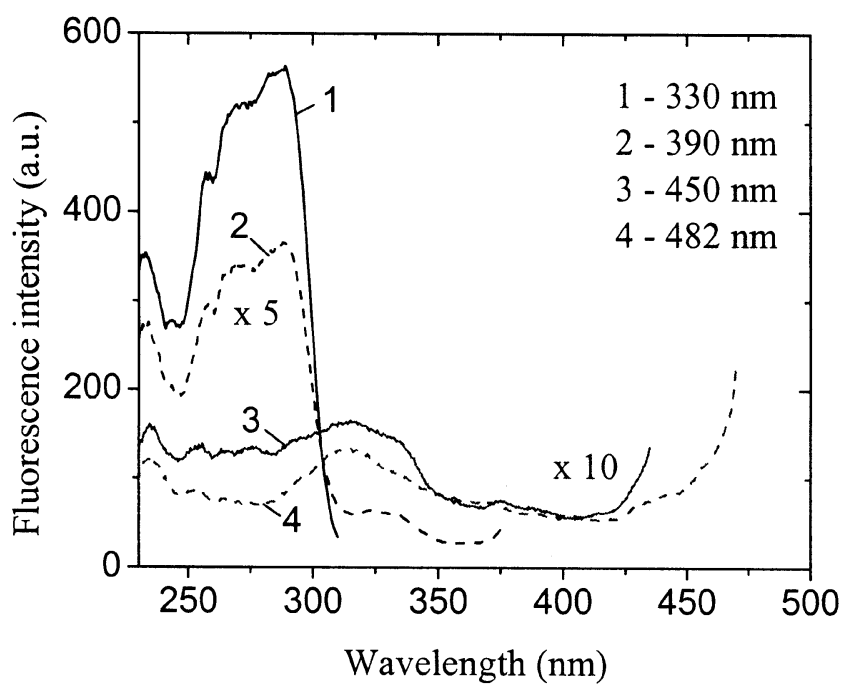

(c)

Fig. 3. Fluorescence excitation spectra of (a,b) HB and (c) MC recorded at different fluorescence wavelengths. The (b) spectra are scaled with respect to the (a) ones by a factor of 5 . 


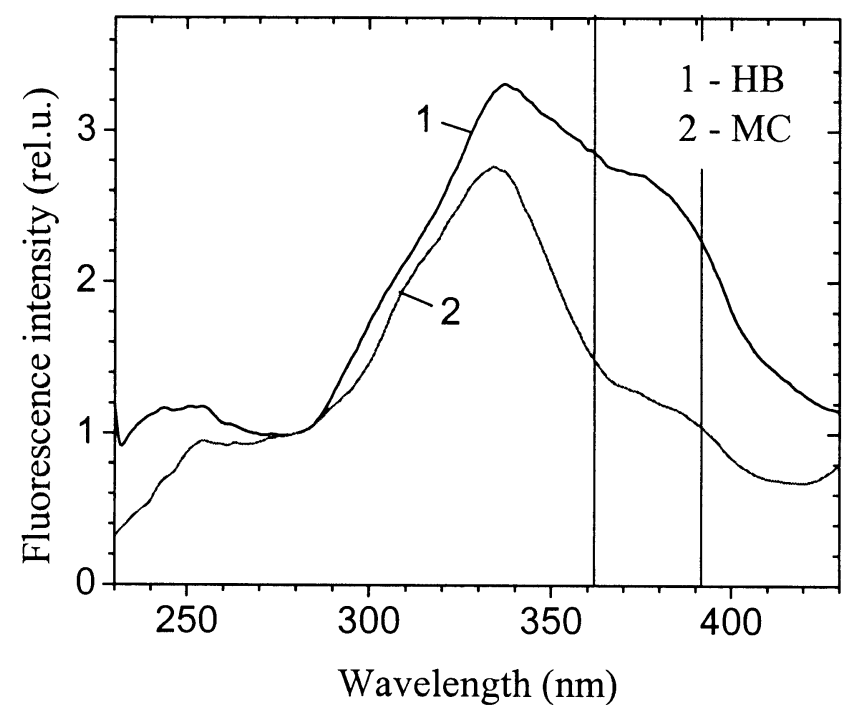

(a)

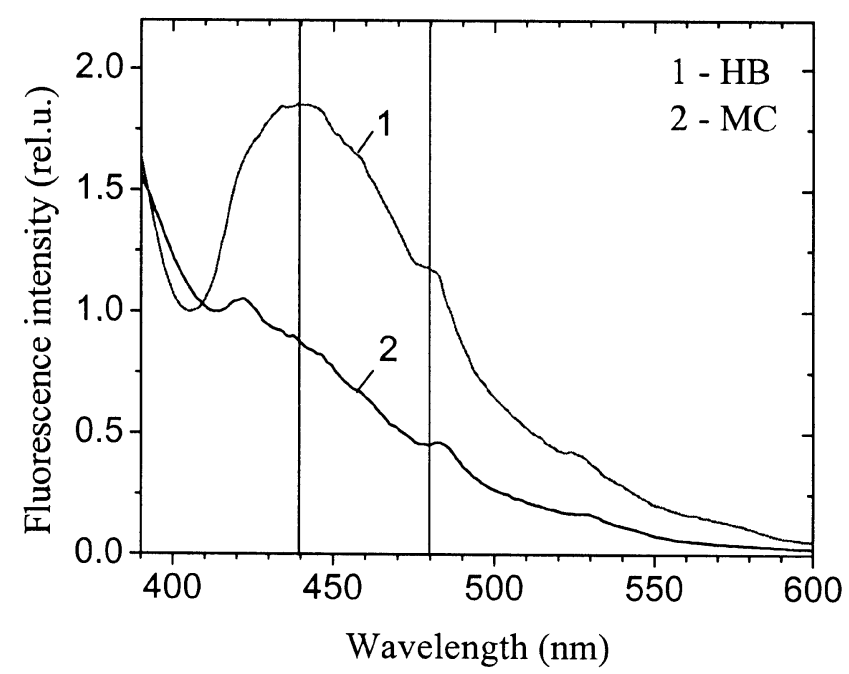

(b)

Fig. 4. (a) Fluorescence excitation spectra, $\lambda_{\mathrm{m}}=450 \mathrm{~nm}$, and (b) fluorescence spectra, $\lambda_{\text {exc }}=360 \mathrm{~nm}$, of $\mathrm{HB}$ and MC normalized at $280 \mathrm{~nm}$ and $410 \mathrm{~nm}$, respectively.

of $\mathrm{HB}$ and MC tissues, which are enlisted in Tables 1 and 2.

The collected spectral data reveal that the maximal difference in intensity of the fluorescence excitation spectra of heart tissues is within the spectral region of $360-390 \mathrm{~nm}$, when the fluorescence is recorded at $450 \mathrm{~nm}$ (Fig. 4(a)). The fluorescence spectra registered under the excitation $\lambda_{\text {exc }} \in[360,390] \mathrm{nm}$ resulted in the largest difference between fluorescence intensities of $\mathrm{HB}$ and MC tissues (Fig. 4(b)).

On the basis of the collected spectral data, preliminary experiments on the visualization of HCS were performed ex vivo under excitation at $360 \mathrm{~nm}$ (Fig. 5). As a fluorescence signal was recorded within a whole range

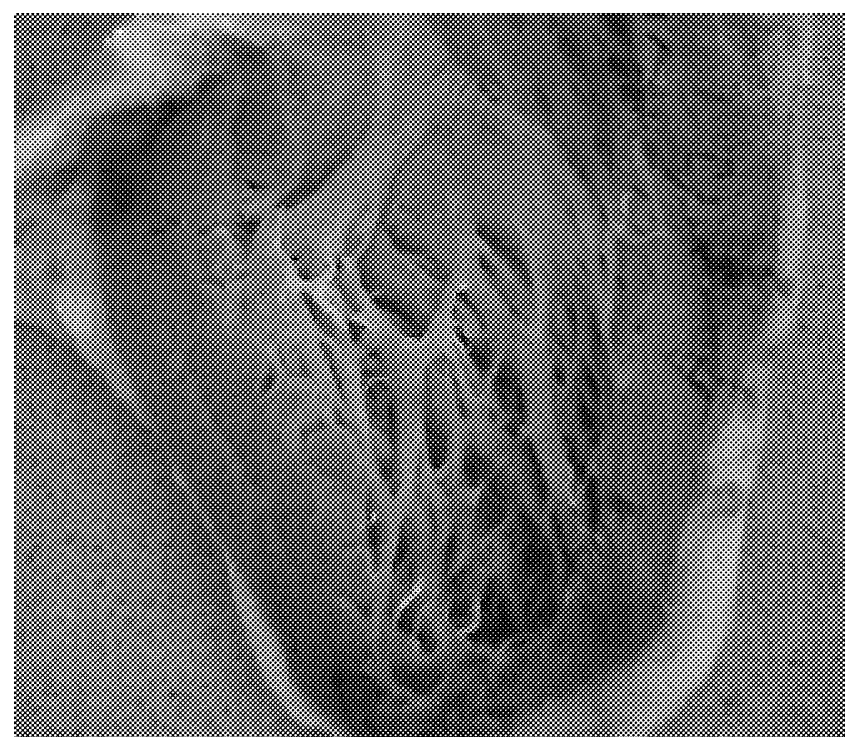

(a)

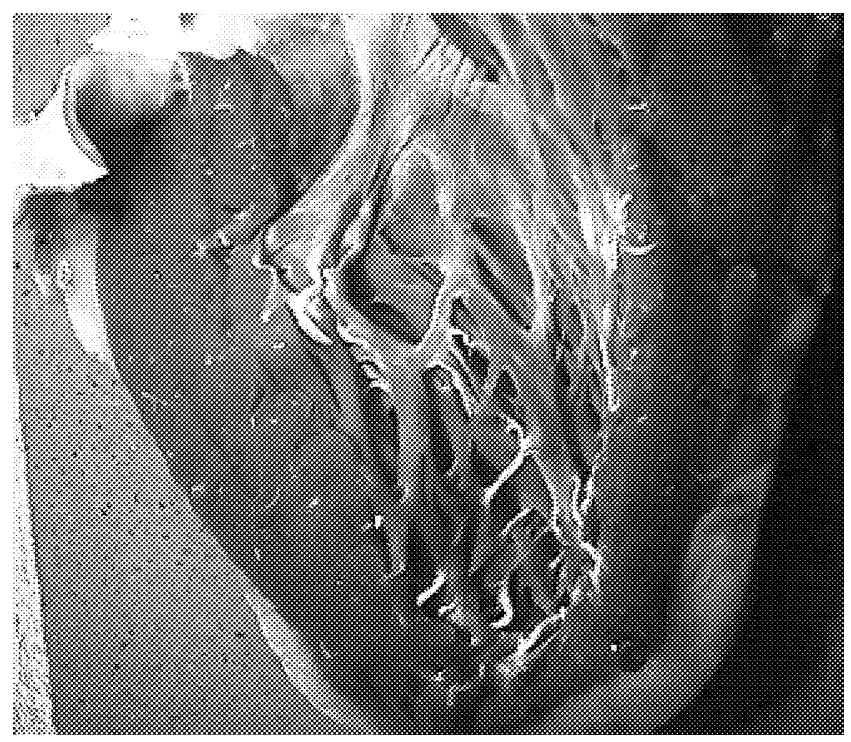

(b)

Fig. 5. Left branch of bundle of His in inter-ventricle septum (a) in the daylight and (b) under $365 \mathrm{~nm}$ excitation, taken in a whole range of visible spectrum.

of the visible light spectrum, not only autofluorescence of HB branch was observed, but also that of other tissues. Therefore, the spectral range of the recorded signal should be narrowed to ensure the selective HCS visualization. That is envisaged to perform during the subsequent research stages.

\section{Conclusions}

Excitation at the absorption band of the aromatic amino acids allows good differentiation between tissues of the bundle of His and those of myocardium 
Table 1. Fluorescence wavelengths $\lambda$ of potential fluorophores responsible for autofluorescence of HB and MC tissues.

\begin{tabular}{|c|c|c|c|}
\hline \multirow{2}{*}{$\begin{array}{l}\lambda_{\text {exc }} \\
(\mathrm{nm})\end{array}$} & \multicolumn{2}{|c|}{$\lambda(\mathrm{nm})$} & \multirow{2}{*}{$\begin{array}{c}\text { Possible } \\
\text { fluorophores }\end{array}$} \\
\hline & $\mathrm{HB}$ & $\mathrm{MC}$ & \\
\hline 255 & 340,425 & 340,425 & $\begin{array}{c}\text { Tryptophan, } \\
\text { N-formylkynurenine }\end{array}$ \\
\hline 330 & 390,425 & $390,450,530$ & Pyridoxine, collagen \\
\hline 366 & 450 & 450 & Kynurenine \\
\hline 385 & 460 & 450 & Kynurenine (?) \\
\hline 430 & $>450$ & $>450$ & Lipopigments, flavins \\
\hline
\end{tabular}

Table 2. Fluorescence excitation wavelengths $\lambda_{\text {exc }}$ of potential fluorophores responsible for autofluorescence of HB and MC tissues. Here $\lambda_{\mathrm{m}}$ is the emission wavelength at which the fluorescence was recorded.

\begin{tabular}{cccc}
\hline$\lambda_{\mathrm{m}}$ & \multicolumn{2}{c}{$\lambda_{\text {exc }}(\mathrm{nm})$} & \\
\cline { 2 - 3 }$(\mathrm{nm})$ & $\mathrm{HB}$ & $\mathrm{MC}$ & $\begin{array}{c}\text { Possible } \\
\text { fluorophores }\end{array}$ \\
\hline 340 & 285 & 285 & Tryptophan \\
390 & 285,330 & 285,330 & Pyridoxine, collagen \\
422 & 330 & 330 & Collagen, elastin \\
445 & 330,383 & 330 & Kynurenine \\
485 & $315,330,390,430$ & 315 & Lipopigments, flavins \\
\hline
\end{tabular}

when the ratios of the fluorescence intensities measured at $340 \mathrm{~nm}$ to those at $450 \mathrm{~nm}$ are compared.

Several fluorophores with overlapping absorption and fluorescence bands are responsible for autofluorescence of heart tissues in the $390-550 \mathrm{~nm}$ spectral range. Their concentration in His bundle seems to be significantly higher than in myocardium.

The tissues of the bundle of His and myocardium are also distinguishable by fluorescence intensity under excitation in the UVA spectral region. The best conditions are ensured by excitation at $\lambda_{\text {exc }}=360-390 \mathrm{~nm}$ and by recording the fluorescence signal in the $440-480 \mathrm{~nm}$ spectral range.

\section{Acknowledgements}

This study has been supported by the Lithuanian State Science and Education Foundation, project K-055.
Authors thank Dr. R. Karpicz (Institute of Physics, Molecular Compounds Physics Laboratory) for help in fluorescence measurements.

\section{References}

[1] D.J. Aziz, A. Caruso, M. Aguire, and A.F. Gmitro, Fluorescence response of selected tissues in the canine heart: An attempt to find the conduction system, in: Diagnostic and Therapeutic Cardiovascular Interventions II, ed. G.S. Abela, Proc. SPIE, Vol. 1642 (1992) pp. 166-175.

[2] G.E. Kochiadakis, S.I. Chrysostomakis, M.D. Kalebubas, G.M. Filippidis, and I.G. Zacharakis, The role of laser induced fluorescence in myocardium tissue characterization: Experimental in vitro study, Chest 120, 233-239 (2001).

[3] M. Perk, G.J. Flynn, S. Gulamhusein, Y. Wen, C. Smith, B. Bathgate, J. Tulip, N.A. Parfrey, and A. Lucas, Laser induced fluorescence identification of sinoatrial and atrioventricular nodal conduction tissue, Pacing Clin. Electrophysiol. 16, 1701-1712 (1993).

[4] E. Žurauskienè, E. Žurauskas, G. Streckyte,, S. Bagdonas, K. Žvaigždinas, and R. Rotomskis, Premises of visualization of the conduction system of heart: Spectroscopic investigations, Lithuanian J. Phys. 41, 505508 (2001).

[5] G.A. Wagnieres, W.M. Star, and B.C. Wilson, In vivo fluorescence spectroscopy and imaging for oncological applications, Photochem. Photobiol. 68, 603-632 (1998).

[6] M. Kwasny and Z. Mierczyk, Application of fluorimetric analysis methods in diagnostics of early phases of tumours, in: Photodynamical Methods of Recognition and Curing, ed. A. Graczykowa (Dom Wydawniczy Bellona, Warszawa, 1999) pp. 300-331 [in Polish].

[7] A. Pirie and K.J. Dilley, Photo-oxidation of N-formylkynurenine and tryptophan peptides by sunlight or simulated sunlight, Photochem. Photobiol. 19, 115-118 (1974).

[8] R.A. Edwards, G. Jickling, and R.J. Turner, The lightinduced reactions of tryptophan with halocompounds, Photochem. Photobiol. 75, 362-368 (2002). 


\title{
ŠIRDIES LAIDŽIOSIOS SISTEMOS VIZUALIZACIJA FLUORESCENCINĖS SPEKTROSKOPIJOS METODU
}

\author{
E. Žurauskas, S. Bagdonas, L. Bandzaitytė, G. Streckytė, R. Rotomskis
}

Vilniaus universitetas, Vilnius, Lietuva

\section{Santrauka}

Tirti širdies laidžiosios sistemos dalies - His'o pluošto ir širdies skilvelių vidiniame paviršiuje esančiu jo šakų bei aplinkinio miokardo - bandiniai, paimti iš skirtingo amžiaus ir skirtingos patologijos širdžiu preparatų, fiksuoti ir nefiksuoti buferiniame formalino tirpale, matuojant savitosios fluorescencijos bei jos žadinimo spektrus. Iš rezultatu matyti, kad šie audiniai pasižymi skirtingais fluorescencijos ir fluorescencijos žadinimo spektrais. Žadinant aromatinių aminorūgščiu sugerties juostoje, galima vienareikšmiškai atskirti His'o pluošto ir miokardo audinius pagal fluorescencijos spektrų intensyvumų ties $340 \mathrm{~nm}$ ir $450 \mathrm{~nm}$ santykį, kuris
His'o pluoštui yra 2,5, o miokardui - 6,4. His'o pluošto ir miokardo audinius pagal jų fluorescencijos intensyvumą galima atskirti ir žadinant ilgesnių bangu spinduliuote, kurios aromatinès aminorūgštys nesugeria. His'o pluošto mėginiuose spektriniame ruože nuo $350 \mathrm{~nm}$ iki $550 \mathrm{~nm}$ fluorescuoja keli fluoroforai, kuriu fluorescencijos spektrai persikloja. Tų fluoroforu fluorescencijos intensyvumas His'o pluošte žymiai didesnis nei miokarde. His'o pluošto ir miokardo audinių fluorescencijos spektrai geriausiai atskiriami žadinant fluorescenciją 360-390 nm ruože. Audinių fluorescencijos signalo registracija $440-480 \mathrm{~nm}$ srityje užtikrintu optimalu širdies laidžiosios sistemos vizualizaciją. 